\title{
Exploring Gender Differences in the Intentions of University Students towards Entrepreneurship
}

\begin{abstract}
Purpose - The purpose of this paper is to understand gender differences in entrepreneurial intentions as measured by perceived feasibility and perceived desirability, and to explore gender differences in perceptions of entrepreneurship education needs - in terms of programmes, activities or projects - to succeed in an entrepreneurial career from the university students' point of view.
\end{abstract}

Design / Methodology /Approach - Using data gathered from 3420 university students in more than 10 countries, and applying the Mann-Whitney non-parametric test, differences between genders and different intention groups were examined. To reduce the items regarding educational needs, factor analysis was used. Gender differences in educational needs were also examined via Mann-Whitney Test.

Findings - The results confirm that compared to males, female students are less willing to start their own businesses. There are significant gender differences in terms of perceived feasibility and perceived desirability such that although they feel more supported by their families, females are less self-confident, more tense, reluctant and concerned about entrepreneurship. In terms of entrepreneurial intention, there are fewer gender differences among students; however, differences relating to self-confidence and family support still exist. Furthermore, students cited establishing entrepreneurial mentoring and an appropriate tutoring structure as the most needed entrepreneurial educational activity/program/project at an academic institution; this was rated higher by females compared to males.

Practical implications - The findings of this paper could help guide educators and policy makers in designing effective entrepreneurship programmes that are customized to respond to gender specific needs to increase entrepreneurial participation.

Originality / Value - This study reveals the gender differences in perceived desirability and perceived feasibility which impact entrepreneurial intentions. Gender differences in the entrepreneurial programmes/activities/projects required at an academic institution to promote entrepreneurial participation among university students is also explored.

Keywords Entrepreneurship, Gender, Education and Training, Perceived Feasibility and Perceived Desirability

Paper type Research paper 


\section{Introduction}

In recent decades, entrepreneurship as a research topic has increased in popularity, due mainly to its positive effects on a country's economic development (Keilbach and Sanders, 2008) in terms of growth, innovation, employment creation and poverty reduction (Lunati et al., 2010). In order to increase participation in entrepreneurial activities, researchers, educators and policy makers need to identify the underlying factors affecting entrepreneurial behaviour and identify ways to stimulate entrepreneurial intentions (Turker and Selcuk, 2009) among those who do not appear to be born "entrepreneurs". Entrepreneurs are seemingly different from their fellow citizens in terms of their tendency to take risks, their tolerance for ambiguity and their motivation for self-employment.

Entrepreneurial motivations have been studied intensely for some time. Early studies examining the topic were, for the most part, focused on traits, such as tolerance of ambiguity, self-confidence and tolerance of risk (Summers, 2000). Subsequently, aspects other than traits such as external influences (politics and capital availability), demographic characteristics (gender, age, and education) and social factors (family and community) have been identified as factors influencing entrepreneurial motivation (Summers, 2000). In this regard, more recent models appear to be intention-based process models (Shapero, 1982). According to Segal et al. (2005) these process models for entrepreneurial motivations are "focusing on attitudes and beliefs and how they can predict intentions and behaviors". These models are based upon the human cognitive processes underpinning an individual's identification of desirable outcomes and their assessment of the feasibility of success in attempting to realise those outcomes.

Although the number of female entrepreneurs has increased in recent years (Brush et al., 2009; de Bruin et al., 2006), the number of female entrepreneurs is still generally lower than the number of the male entrepreneurs (GEM, 2010). A review of the entrepreneurship literature reinforces this. For example, as a result of the evaluation of $15 \mathrm{EU}$ member countries and the US, Grilo and Irigoyen (2005) found that self-employment is more preferred by men than women. Wilson et al. (2004) suggest that among teens, boys are more willing to engage in entrepreneurial activities in comparison to girls. Also according to Wilson et al. (2007) female high school and MBA program students show lower entrepreneurial selfefficacy than male students. Zhang et al. (2009) suggest that gender differences regarding entrepreneurial intentions are due to the genetic basis of entrepreneurship. Since female and 
male entrepreneurs usually operate in different sectors and pursue different ways to develop their business, an increased number of female entrepreneurs will also increase the variety of entrepreneurship in the economy (Verheul et al. 2004). Thus, examining entrepreneurial behavior from a gender perspective can help educators and policy makers improve the participation of females in entrepreneurial activities by revealing the differences between genders. Thus, an environment that considers both genders' needs can be created.

One way of improving participation in entrepreneurial activities is to organise effective entrepreneurship education programmes or implement appropriate activities/projects in existing business schools to promote students' success in an entrepreneurial career. In recent years, entrepreneurship education in higher education has come into prominence (Wilson et al., 2004). According to Krueger and Brazeal (1994), entrepreneurial training should provide the relevant self-confidence through "emotional and psychological support", "credible role models" and the knowledge needed by potential entrepreneurs to start and manage a business. Menzies and Tatroff's (2006) work on gender differences in preferences on entrepreneurship education states that fewer women are interested in entrepreneurship education compared to men. One of the factors influencing that finding could be, as cited by Wilson et al. (2004), that programmes and curricula are arranged without pondering the differences in perceptions and motivations of the different genders.

The purpose of this paper is to build upon earlier work (for example, Dabic et al., 2012) and examine whether gender has a significant impact on the entrepreneurial intentions of university students, as measured by perceived feasibility and perceived desirability, and on the perceived educational needs at academic institutions in terms of entrepreneurial training. In Dabic et al. (2012), the sample was clustered into four groups. The first cluster was created from the questionnaires collected in Israel, with the reasoning that Israel is a country with a high entrepreneurial culture, a high level of development but a low level of political integration. The second cluster consisted of countries that have been in the EU for a longer period of time, namely France and Austria. These two countries have a high level of economic and political development and integration. The third cluster was comprised of Lithuania, Poland and Slovenia; this cluster comprised of countries that recently joined the EU and were characterised by a medium level of political and economic development and integration. The fourth cluster was formed of only one country, namely Croatia, as it is a country awaiting its accession to the EU and which, despite making a number of political and economic reforms 
had a low level of political integration and lower level of development than the previous three clusters. In our study, however, perceived desirability, perceived feasibility and educational needs in terms of entrepreneurial programmes, activities and projects at an academic institution were analyzed from the gender difference perspective only. We focus only on these specific elements as they provide a foundation for improving the educational capabilities of the entrepreneurship curriculum to foster innovation and creative performance. Given that entrepreneurs are reported to have a greater need for achievement than the general population (Hines, 1973), the possible recommendations for curricula improvement relate to the mass customization of motivations and entrepreneurial orientations of students as institutions are unable to tailor and deliver fully individualised programmes (Elenurm et al., 2007).

This paper focuses on university (undergraduate and graduate) students on the basis that younger people are more willing to be self-employed (Blanchflower et al., 2001; Grilo and Irigoyen, 2005), and that willingness to be self-employed decreases with age (Fernandez et al., 2009). Also, according to GEM's 2010 global report, with regard to the age distribution of entrepreneurs, the 24-35 age group has the highest population for almost every geographic region. Therefore, in terms of developing future potential entrepreneurs, examining university students' entrepreneurial intentions, could have some valuable implications.

The next section of the paper examines gender differences in the entrepreneurship literature, as well as the entrepreneurial intentions model applications literature. The focus is on university students and gender differences, including the effect of entrepreneurial education on entrepreneurial intentions. Hypotheses are then introduced, and these are followed by a description of the research design and the methodology adopted. The paper concludes with a discussion of the findings and some recommendations for future research.

\section{Background Information and Hypotheses}

\section{Entrepreneurial intention models}

Intention is an anterior to act (Ajzen, 1991); it is the first step to initiating an action: "Intentions capture the motivational factors which influence behaviour, indicating the effort the individual plans to exert to put this behaviour into practice" (Linan and Santos, 2007). Bagozzi et al. (1989) state that intentions are the single best predictor of planned behaviour. 
As with all other behaviour types, intention is also the driving force in entrepreneurial behaviour ( $\mathrm{Wu}$ and $\mathrm{Wu}, 2008$ ). According to relevant studies conducted on entrepreneurial behaviour, intention's ability to explain entrepreneurial behaviour is better than other sources, such as demographic characteristics or external influences (Wu and $\mathrm{Wu}, 2008$; Krueger et al., 2000).

Entrepreneurial intentions have been studied in the entrepreneurship literature for some time. From the early 1980s, many entrepreneurial intention models have been developed (e.g. Shapero, 1982; Ajzen, 1991; Krueger and Brazeal, 1994). The most accepted intention models are Shapero's (1982) Entrepreneurial Event Model and Ajzen's (1991) Theory of Planned Behaviour. Both models feature intentions as predictors of entrepreneurial behaviour. Shapero's (1982) model, for example, suggests that entrepreneurial intentions are directly shaped by perceived feasibility and perceived desirability of entrepreneurial activity and propensity to act. Ajzen's (1991) Theory of Planned Behaviour claims that attitude towards the act (or personal attraction (Linan and Santos, 2007)), social norms (or perceived pressure from other people (Linan and Santos, 2007; Guerrero et al., 2008)) and perceived behavioural control (or self-efficacy (Linan and Santos, 2007)) have an influence on entrepreneurial intention. Two elements from each model are similar: perceived feasibility aligns with perceived behavioural control and perceived desirability with attitude towards the act (Linan and Santos, 2007; Fitzsimmons and Douglas, 2010)). In a study conducted by Krueger at al. (2000), Ajzen's (1991) and Shapero's (1982) theories were compared, and strong statistical support for both models was offered. It was concluded that intentions were the single best predictors, while personal and situational variables provided a small amount of explanatory power for entrepreneurial behaviour.

Linan (2008) stresses the role of society in encouraging entrepreneurial behaviour, suggesting that individuals are more inclined towards entrepreneurship in environments that approve their choice. In contrast to previous studies conducted (Krueger, 1993; Krueger and Brazeal, 1994), which indicated that both high perceived feasibility and perceived desirability lead to strong entrepreneurial intentions, Fitzsimmons and Douglas (2010) suggested that only one high effect, i.e., high perceived desirability or high perceived feasibility, might also lead to strong entrepreneurial intentions. However, to understand which factors have an influence on entrepreneurial perceptions further studies are needed (Linan and Chen, 2009). In this study perceived desirability and perceived feasibility were defined as follows: perceived desirability 
is the personal attractiveness of starting a business, which incorporates intrapersonal and extra personal impacts, while feasibility relates to the degree to which one feels personally capable of starting a business, where attitudes are linked to expected gains from key outcomes.

\section{Gender and Entrepreneurship}

Although the number of women in self-employment is increasing throughout the world, they are still outnumbered by male entrepreneurs. According to Minniti et al. (2005) women are less likely to be self-employed, especially in middle-income countries, with a ratio of $75 \%$. In the entrepreneurship literature there are several studies that seek to understand the factors and decision processes that affect females and males differently in terms of their interest in entrepreneurial activities. One of the most studied factors, which is regarded as a contributor to the behavioural difference towards entrepreneurship among genders is self-efficacy. According to Wilson et al. (2007) "self-efficacy, or self confidence, is based on individuals' perceptions of their skills and abilities". People with higher self-efficacy levels for a given task are expected to be more willing to do that task (Bandura, 1997). According to Minniti and Nardone (2007), "Attitudes toward entrepreneurship reflect, to a large extent, subjective perceptions rather than objective conditions", and if women thought they had the skills and abilities needed to achieve success, they would be more willing to start their own business. The entrepreneurship literature frequently mentions that females have lower self efficacy levels in areas associated with business success, such as quantitative skills, problem solving, money management (Marlino and Wilson, 2003), and less entrepreneurial interest compared to males (Wilson et al., 2007; Wilson et al., 2004; Kirkwood, 2009; Kourilsky and Walstad, 1998; Marlino and Wilson, 2003; Minniti and Nardone, 2007; Fernandez et al., 2009). Some studies also indicate that females, teenage or adult, are more responsive to self-efficacy. This means that low levels of self-efficacy, resulting from the perceived absence of necessary skills and abilities, influence females more negatively in terms of entrepreneurial intentions. Thus, self-efficacy plays a more significant role in the entrepreneurial behaviour of females compared to males (Kickul et al., 2008; Bandura et al., 2001).

Although there is no consensus in the literature on women's risk-taking ability (Minniti and Nardone, 2007), there is a perception that women have less risk tolerance than men (e.g. Butner and Rosen, 1988). Lower risk tolerance (or higher risk perception) is expected to impact the entrepreneurial intention negatively (Fernandez et al., 2009). Menzies and Tatroff 
(2006) studied the entrepreneurial attitudes of Canadian students, and although they reported no difference toward risk-taking, they found that female students differed from their male counterparts in not choosing an entrepreneurship focus, stating that entrepreneurship "wouldn't fit their personality."

Being less risk tolerant is also seen as a consequence of fear of failure (Arenius and Minniti, 2005). According to Minniti and Nardone (2007), although being risk tolerant may contribute to the difference among genders in attitudes towards entrepreneurship, "what matters is not the respondents' fear of failure, rather, it is the degree to which fear of failure affects the behavior of individuals." Perceived difficulties in accessing financial support to start a business can also affect entrepreneurial intention negatively (Roper and Scott, 2009). When they investigated the relationship between gender and perceived financial barriers among women in the UK, Roper and Scott (2009) found that women were more likely to have a fear of financial barriers when starting a business.

The literature also reports that motivations for entrepreneurship differ among genders (Marlino and Wilson, 2003; Wilson et al., 2004). According to Wilson et al.'s 2004 study conducted among teenagers, while female participants willing to start their own business were more influenced by social and relational motivations such as being respected, helping others and providing jobs, males were more motivated by the autonomous nature of entrepreneurship. Consistent with this finding, Marlino and Wilson (2003) found in their study that most middle and high school girls perceived business as "hard, complicated and risky", showing less interest in being self-employed compared to boys. They also found that girls interested in business as a future career path acted in much the same way as boys with similar career interests, and that they acted differently to girls interested in non-business career opportunities (Marlino and Wilson, 2003). This supports findings by Gupta et al. (2009), who examined the relationship between gender stereotypes and entrepreneurial intentions. They reported that entrepreneurial behaviour is linked to "masculine gender-role stereotype" characteristics rather than biological sex. Furthermore, surprisingly they did not find any significant difference between genders regarding entrepreneurial intentions (Gupta et al., 2009). In a similar vein, there are other recent studies suggesting that perceptual factors in starting a business such as risk tolerance, self-efficacy and knowing other entrepreneurs are not gender dependent (Arenius and Minniti, 2005). Arenius and Minniti (2005) claimed that perceptual factors are "drivers of entrepreneurial behavior for both genders" and since these 
factors are subjective they might be biased. Similarly, Mueller and Dato-on (2008) presented evidence that entrepreneurial self-efficacy is more "gender-role orientation" than biological sex dependent. They studied the relationship between "gender-role orientation", i.e., socially constructed gender behavior patterns, and entrepreneurial self-efficacy and found that the relationship is versatile for different phases of starting a business. Watson and Newby (2005) investigated the relationship between SME owner attributes and birth gender and gender-role orientation and concluded that gender-role orientation (or "stereotypical sex-roles") might be a better indicator when studying differences between male and female owners' attributes. They suggested that, among all attributes, such as "locus of control", "manifest needs" and "preference for innovation", it was only in "risk-taking propensity" that male SME owners scored higher than female SME owners (Watson and Newby, 2005).

Intention-based process models have also been used to illustrate differences between male and female entrepreneurial behaviours. For example, Veciana et al. (2005) used entrepreneurial intention models to compare university students' attitudes towards entrepreneurship in Catalonia and Puerto Rico. They found that in Catalonia male students showed higher desirability towards entrepreneurship and were more serious about creating a new venture compared to female students. Guerro et al. (2008), use an intentional model to assess the attitudes of Catalonian university students towards entrepreneurship, finding that, consistent with Veciana et al. (2005), students' desirability to start a new business is stronger than actual feasibility. Finally, El Harbi et al. (2009) explored the entrepreneurial intentions of young males and females in Tunisia. Their findings suggest that entrepreneurial intentions vary with gender and are grounded on traditional social norms.

\section{Entrepreneurship Education}

Peterman and Kennedy's (2003) study on the impact of attendance at enterprise education programmes on perceived desirability and perceived feasibility towards entrepreneurship found that students' perceived feasibility and desirability levels increased after completing the programme. Indeed, there are several studies citing the importance of entrepreneurial education/training programmes on entrepreneurial behavior (e.g. Turker and Selcuk, 2008; $\mathrm{Wu}$ and $\mathrm{Wu}, 2008$; Wang and Wong, 2004). Given that perceived feasibility and desirability designate intention, which is anterior to action, one can see how effective entrepreneurial education could be highly beneficial to economic development (Linan, 2004). Indeed, Wilson 
et al. (2007) suggest that entrepreneurship education has a much stronger impact on female students in terms of improved self-efficacy, a finding supported by Cooney (2009), who found that a pilot entrepreneurial programme conducted with female travellers increased their level of self-confidence.

In their paper on the relationship between personally knowing an 'entrepreneurial' role model and engagement in entrepreneurial careers, Klyver and Grant (2010) claimed that having an entrepreneur acquaintance has a positive impact on entrepreneurial intentions. Arenius and Minniti (2005), and Fernandez et al. (2009) observed that knowing an entrepreneur is one of the predictors of entrepreneurial behavior. Similarly, Linan and Santos (2007) analyzed the effect of social capital, defined as a "whole set of relationships individuals have", on perceived feasibility and desirability toward entrepreneurial intention. Their results revealed that knowing entrepreneurial role models other than family members, having contacts with entrepreneurial networks and "start-up support bodies" have a positive impact on perceived feasibility but not on desirability. They also indicated that having approval from closer circles for starting a business would increase perceived feasibility. However, the entrepreneurship literature generally assumes that women are less likely to know an entrepreneur personally. Entrepreneurship education/training may also fill this gap by providing an entrepreneurial network for women. In this regard, Tynan et al. (2009) considered the networks developed between the participants of the FEIW (Female Entrepreneurship Ireland and Wales) project to be just as important as the training itself. They also underlined the importance of mentoring in an entrepreneurship program. They concluded that an entrepreneurship training programme intended for women should help develop both "soft skills" (self esteem, networking etc.) and "hard skills" (technical knowledge).

According to Petridou et al. (2009), there are differences between men and women in terms of their attitudes towards entrepreneurship education and their perceptions of the skills required for successful entrepreneurship. To support female entrepreneurs, training/education must be customised to meet women's needs (Dhaliwal, 2010). Similarly, Kourilsky and Walstad (1998) suggested that the entrepreneurship education curriculum must take account of the possibility that women might be less self-confident and less motivated compared to men. Roomi and Harrison (2010) further suggested that women-only training programmes can help female entrepreneurs to overcome barriers. These studies show that some of the factors attributed to low entrepreneurial participation of females, such as lower self-efficacy, lack of 
networking and an absence of role models, can actually be eliminated or alleviated to some degree through the development of an entrepreneurial education/training programme that is customized according to the needs of both genders.

Based on the discussion above we hypothesize as follows:

H1 - There is a significant gender difference in students' willingness to start their own business.

H2 - There is a significant gender difference in students' intentions towards entrepreneurship as measured by desirability and feasibility.

H3 - Among students willing and not willing to start their own business, there is a significant gender difference in students' intentions towards entrepreneurship as measured by desirability and feasibility.

H4 - For the same gender, there is a significant difference between students willing to start one's own business and others in terms of intentions towards entrepreneurship as measured by desirability and feasibility.

H5 - There is a significant gender difference in students' perceptions towards the academic programmes/activities/projects required to prompt success in an entrepreneurial career.

Studying differences between men and women in perceived desirability and feasibility towards entrepreneurship could help reveal the critical factors influencing intentions. This will allow us to see how these areas overlap with the different educational/training needs of men and women, and whether there are any gender differences. An overlap would show that respondents are aware of their perceived weaknesses to start a business and that they are willing to overcome these by participating in appropriate education/training programmes.

\section{Research Design and Methodology}

We base our methodological approach on Shapero's (1982) model of entrepreneurial potential and Ajzen's (1991) theory of planned behaviour, as both models overlap in perceived feasibility and perceived desirability. Perceived desirability is the personal appeal of starting a business, which incorporates "intrapersonal and extra personal impacts", while perceived feasibility relates to the "degree to which one feels personally capable of starting a business", 
where attitudes and expected gains from key outcomes are linked (Krueger et al., 2000). In this regard, perceived self-efficacy is a prerequisite of perceived feasibility (Krueger et al., 2000).

It is generally agreed that there are some elements of entrepreneurship which can be developed through targeted education or training programme (Henry et al., 2005 a, b) and, as mentioned above, it has been observed that perceived feasibility and perceived desirability are positively influenced by entrepreneurial education (Peterman and Kennedy, 2003). Furthermore, Krueger et al. (2000) indicate that through targeted training, entrepreneurial self-efficacy, which is accepted as a factor that caused gender differences in entrepreneurial intentions, can be increased.

Accordingly, a model (Figure 1), which provides insights into the entrepreneurial intentions of students in terms of gender differences, is constructed. It is assumed that gender has an indirect impact on entrepreneurial intentions through perceived feasibility and desirability. It is also expected that gender affects students' expectations from an academic entrepreneurship program, activity or project. The solid lines in the diagram depicted in Figure 1 indicate the particular aspects addressed in this paper.

\section{Gender}

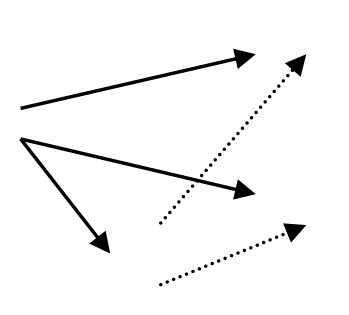

\section{Desirah}

\section{Educati}

Figure 1 - Research Framework

Identifying university students' perceptions of new venture desirability and feasibility is important for any university aiming to foster, awaken and stimulate students' interest in an entrepreneurial career. The inclination of the student population, in particular the senior student population, towards entrepreneurship is a matter of particular interest due to the 
established interrelatedness between education and self-employment. Essentially, it is assumed that the knowledge and skills acquired in the process of higher education actually encourage people to set up their own businesses as a very acceptable means of entering the labour market. Having conducted research on the entrepreneurial inclination of students in the final years of their under- and post-graduate study programmes, in 2009, the Faculty of Economics carried out a study of the entrepreneurial aptitudes of university student populations. The study was part of the European Commission's Tempus project 'Fostering Entrepreneurship in Higher Education'.

A survey instrument was developed and data were collected from more than 4,000 students. This yielded 3,420 valid responses from more than 10 countries (Croatia, Austria, Belgium France, Israel, Lithuania, Poland, Slovenia, India and the 'rest of the world'). 2,173 of the respondents were female students and 1,247 were male. While $60 \%$ of the respondents were in the 21-25 year age group, $24 \%$ were 20 years old or younger, with the remainder being 26 or older. Most of them were in their first year of undergraduate study (39.6\%), with some following their second year $(27.9 \%)$ or their third year $(15.9 \%)$ of study. Some $(12.1 \%)$ were in their 1 st year of postgraduate study, with $4.5 \%$ in their 2 nd year of postgraduate study.

To assess the entrepreneurial intention of students, the respondents were asked what they intended to do after graduation. The choices included "start a new business (alone or with a partner)", "work for an immediate family member's company" and "work for someone else in a small or large corporation". In this theoretical framework, to examine the concept of perceived desirability, respondents were asked to indicate the degree to which they agreed with the following statements with regard to starting their own businesses upon graduation: (1) "I would love to do it"; (2) "My immediate family members would encourage me to do it"; (3) "I would be tense"; (4) "I would be enthusiastic". Respondents used a Likert scale, where 1 represented "did not agree at all" and 6 equalled "completely agree". In order to investigate respondents' perceptions of the feasibility of starting a new business, the following statements were included in the survey: (1) "It would be very hard to do"; (2) "I am certain that I would be successful"; (3) "I would be overworked"; (4) "I know enough to start a business"; (5) "I trust myself". To evaluate each statement, respondents were again asked to answer on a Likert scale of 1 to 6 , this time with 1 being "very much agree", and 6 being "very much disagree". 
To examine students' perspectives on the university entrepreneurial programmes, activities or projects required to succeed in an entrepreneurial career, twenty statements (Table 1) regarding these institutional entrepreneurial offerings were assessed by respondents on a 6point Likert scale, with 1 representing "not needed at all" and 6 "very much needed".

Table 1. Potential entrepreneurship education needs to be met by academic institutions

\section{Programmes / Activities / Projects}

1. Creating specific programmes in entrepreneurship

2. Incorporating courses in entrepreneurship within academic programmes such as: management, engineering, technology, medicine, etc.

3. Developing internship programmes in entrepreneurship

4. Creating incubators to support students' initiatives

5. Establishing websites for networking, designed specifically for students wishing to become entrepreneurs

6. Establishing websites for tutoring in entrepreneurship, designed specifically for students wishing to become entrepreneurs

7. Constructing formal and ongoing networking sessions with existing/successful entrepreneurs

8. Practical involvement of lecturers, teachers and/or course assistants in entrepreneurship

9. Constructing formal, ongoing visits to entrepreneurial enterprises

10. Constructing formal, ongoing visits to incubators

11. Developing a well-established research center for entrepreneurship

12. Developing a meaningful relationship with the community

13. Committing to robust, rigorous research in entrepreneurship at the school/department (including publication in the best journals)

14. Developing exchange programmes with students in entrepreneurship programmes at different academic institutions, or in different cities or countries

15. Commitment of senior administrators (e.g., entrepreneurship program directors, deans, advisory board members, etc.) to creating and sustaining performance excellence with a focus on students

16. Commitment to developing a special focus on innovation (e.g., through the curriculum, projects, etc.)

17. Building practical courses that teach best practices in entrepreneurship

18. Studying in small groups or teams (e.g., in preparing classwork and homework, etc.)

19. Commitment to expanding students' networking through professors and other students

20. Developing workshops to practice entrepreneurial 'know-how' 


\section{Results}

Gender differences in starting a new business

To examine the association between gender and willingness to start a new business (Hypothesis 1 - There is a significant gender difference in students' willingness to start their own business), a Chi-square test for independence was conducted. The two categorical variables are determined as gender (male/female) and willingness to start a business (yes/no). We found that there is a significant difference between female and male respondents regarding willingness to start a new business. $\left(X^{2}=99,486\right.$ and $\left.p<0.05\right)$. As can be seen in Table 2, while only $26.8 \%$ of females were interested in starting their own business, $43.5 \%$ of males had entrepreneurial intentions. In general, only $32.9 \%$ of respondents displayed entrepreneurial intentions. This result confirms our hypothesis and is consistent with previous work suggesting that women are less entrepreneurially oriented.

Table 2. Cross tabulation of Chi-square test

\begin{tabular}{|c|c|c|c|c|c|}
\hline & & & \multicolumn{2}{|c|}{ Start own business } & \multirow[t]{2}{*}{ Total } \\
\hline & & & No & Yes & \\
\hline \multirow[t]{8}{*}{ GendeI } & Female & Count & 1590 & 583 & 2173 \\
\hline & & Expected Count & 1457.6 & 715.4 & 2173,0 \\
\hline & & $\%$ within Gender & $73.2 \%$ & $26.8 \%$ & $100,0 \%$ \\
\hline & & $\%$ within Start o. $\mathbf{b}$. & $69.3 \%$ & $51.8 \%$ & $63,5 \%$ \\
\hline & Male & Count & 704 & 543 & 1247 \\
\hline & & Expected Count & 836.4 & 410.6 & 1247,0 \\
\hline & & \% within Gender & $56.5 \%$ & $43.5 \%$ & $100,0 \%$ \\
\hline & & $\%$ within Start o. b. & $30.7 \%$ & $48.2 \%$ & $36,5 \%$ \\
\hline \multirow[t]{4}{*}{ Total } & & Count & 2294 & 1126 & 3420 \\
\hline & & Expected Count & 2294,0 & 1126.0 & 3420.0 \\
\hline & & $\%$ within Gender & $67,1 \%$ & $32.9 \%$ & $100.0 \%$ \\
\hline & & $\%$ within Start o. b. & $100,0 \%$ & $100.0 \%$ & $100.0 \%$ \\
\hline
\end{tabular}

Gender differences in entrepreneurial intentions as measured by perceived desirability and perceived feasibility

To examine whether males and females differ in terms of their perceived desirability and perceived feasibility towards entrepreneurship (Hypothesis 2 - there is a significant gender difference in students' intentions towards entrepreneurship as measured by desirability and 
feasibility) the Mann-Whitney non-parametric test was used. Since the assumptions of parametric tests are violated, to test the differences between two groups, gender in our case, the Mann-Whitney test was preferred for the analysis. As illustrated in Table 3 (in the column headed 'gender'), since all p-values are smaller than the significance level of 5\%, there is a significant gender difference regarding every statement for perceived feasibility and perceived desirability. For responses to statements F1, F3, D1 and D4, male students ranked higher than females. This demonstrates that with respect to perceived feasibility male students are more confident regarding their knowledge and future success (F2, F4 and F5), and are less concerned about the potential difficulties they might encounter in an entrepreneurial activity (F1 and F3). In terms of perceived desirability, again male students display higher aspiration toward entrepreneurship, with higher rankings in D1 and D4. Higher ranking of females regarding D3 is consistent with their lower ranking of D1 and D4, illustrating greater concern and reluctance towards entrepreneurship compared to male respondents. Interestingly, female students are more confident about their families support, although they seem more concerned and insecure regarding entrepreneurial activity. Furthermore, if we look at the mean values, although there is a significant difference between genders, for both genders F4 is the highest scoring feasibility statement. This shows that students are aware of their entrepreneurial knowledge deficit. In terms of perceived desirability, while D2 is the factor with the highest score for females, D4 is the highest scoring factor for males. 
Table 3. Summary of Gender Differences - *** $\mathrm{p}<0.001, * * \mathrm{p}<0.01, * \mathrm{p}<0.05$

Gender: Gender differences in perceived feasibility and perceived desirability towards entrepreneurship (Female/Male)

Start: Gender differences in perceived feasibility and desirability in the case of showing willingness to start a new business. (Female/Male)

Not Start: Gender differences in perceived feasibility and desirability in the case of NOT willing to start a new business. (Female/Male) Female: Entrepreneurial intention-based differences as measured by perceived feasibility and desirability for the female sex (Yes/No) Male: Entrepreneurial intention-based differences as measured by perceived feasibility and desirability for the male sex (Yes/No)

\begin{tabular}{|c|c|c|c|c|c|}
\hline $\begin{array}{l}\text { Perceived Feasibility ( } 1 \text { very much agree, } 6 \text { very much } \\
\text { disagree) }\end{array}$ & Gender & Start & $\begin{array}{l}\text { Not } \\
\text { Start }\end{array}$ & Female & Male \\
\hline F1 - It would be very hard to do. & $* * *$ & & * & $* * *$ & $* *$ \\
\hline F2 - I am certain that I would be successful. & $* * *$ & $* *$ & $* * *$ & $* * *$ & $* * *$ \\
\hline F3 - I would be overworked. & $* *$ & & $* *$ & $* * *$ & \\
\hline F4 - I know enough to start a business. & $* * *$ & & $* *$ & $* * *$ & $* * *$ \\
\hline F5 - I trust myself & $* * *$ & $* * *$ & $* * *$ & $* * *$ & $* * *$ \\
\hline \multicolumn{6}{|l|}{ Perceived Desirability (1 not at all, 6 extremely) } \\
\hline D1 - I would love doing it & $* * *$ & & $* * *$ & $* * *$ & $* * *$ \\
\hline $\begin{array}{l}\text { D2 - My immediate family members would encourage } \\
\text { me doing it }\end{array}$ & ** & $* * *$ & & $* * *$ & $*$ \\
\hline D3 - I would be tense & $* *$ & & & $* * *$ & $* *$ \\
\hline D4 - I would be enthusiastic & $* * *$ & & $* * *$ & $* * *$ & $* * *$ \\
\hline
\end{tabular}


This analysis was done without considering respondents' willingness to start their own business. However, it can be expected that students having the same future intentions towards starting a new business might exhibit higher perceptive similarities in terms of feasibility and desirability, and thus, there might be lower gender differences.

Gender differences in entrepreneurial intentions as measured by perceived desirability and perceived feasibility in the case of having the same entrepreneurial intentions.

To test H3 (among students willing and not willing to start their own business, there is a significant gender difference in students' intentions towards entrepreneurship as measured by desirability and feasibility), we first examined whether there is a significant gender difference among the students who are willing to start a new business in terms of perceived feasibility and desirability. To compare the two independent groups, the Mann-Whitney test was again used. The results of the analysis can be seen in Table 3 (Column Start). As expected, there are fewer differences revealed between genders with regard to feasibility and desirability statements. There is no significant gender difference in F1, F3, F4, D1, D3 and D4. Thus, in F2 and F5, female respondents ranked higher than males, implying that females are less certain of their success and less self-confident. Here, again, a higher female ranking in D2 shows that female students feel more supported by their families in starting a new venture. Consistent with the previous analysis, F4 is the statement with the highest mean score for both genders. Distinctively, D1 has the highest mean values among the desirability statements for both genders.

The same analysis was also conducted for the students who are not willing to start a new business. The results are displayed in Table 3 (column headed 'not start'). In this case, except for D2 and D3, for every statement a gender difference was observed. The direction of the difference is in favour of male students. The male students ranked higher for F1, F3, D1 and D4, showing that, although they do not have the intention to start a new business, they have more positive perceptions about the challenges they would face in the case of starting a new business, and they have higher self efficacy and eagerness towards entrepreneurship. Interestingly, there was no gender difference in family support and concern towards entrepreneurship. Here, again, while F4 has the highest mean score for both genders among feasibility statements, D2 is the most agreed desirability statement among students from both 
genders. The gender difference in F4 illustrates that females are less confident in their entrepreneurial knowledge.

These results reveal that, in the case of willingness to start a new business, genders differ less in terms of perceived feasibility and perceived desirability. However, regardless of their entrepreneurial intentions, female respondents show lower self-esteem and are less confident about their entrepreneurial success. This begs the question 'would entrepreneurial intentions reflect differences in terms of perceived feasibility and desirability in the same gender?'

Differences in perceived desirability and perceived feasibility according to the entrepreneurial intentions of students in the same gender.

To determine the reflection of entrepreneurial intentions as perceived feasibility and desirability measures for the same sex, the analysis was conducted firstly among female respondents. To examine the differences, the Mann-Whitney test was used. Results are displayed in Table 3 (column headed 'female'). As expected, since perceived feasibility and perceived desirability are antecedents of entrepreneurial intentions (Shapero, 1982), different entrepreneurial intentions are led by differences in perceived feasibility and perceived desirability statements. As expected, female students willing to start their own business after graduation have more positive perceptions regarding the difficulties they might face (Higher $\mathrm{F} 1$ and $\mathrm{F} 3$ ranks), are more confident in themselves and in their potential success (lower F2, F4 and F5 ranks), are more eager (higher D1 and D4, lower D3 ranks) and feel they get more support from their families (higher D2).

The same analysis was repeated for the male sex, with the results presented in Table 3 (see column headed ' male'). This time, for all statements except F3 (I would be overworked), a significant difference has been found. The direction of the differences reveals a similar pattern to that of the female sex, suggesting that male students who are willing to start their own business upon graduation have more positive perceptions regarding the difficulties they might face (Higher F1 rank), are more confident in themselves and in their success (lower F2, F4 and F5 ranks), are more eager (Higher D1 and D4, lower D3 ranks) and feel they get more support from their families (higher D2). For both groups of students (willing and not willing to start their own business), and in both sexes, once again the highest scoring feasibility statement is F4. With regard to the highest scored desirability statement, consistent with 
previous analysis, D1 scored highest for students willing to start a business, and D2 scored highest for those not willing to start a business.

Gender differences in educational needs in terms of entrepreneurial programmes/activities/projects at an academic institution

Part of the survey was designed to investigate students' opinion on the entrepreneurial programmes, activities and projects at their academic institution deemed necessary for fostering entrepreneurship. Students were provided with a series of statements to which they answered on a 6-point Likert scale, with 1 representing "not needed at all" and 6 representing "very much needed". The statements are provided in Table 1. To find and analyse the underlying constructs, exploratory factor analysis (as an extraction method principle component analysis with varimax rotation) was applied. The analysis produced 3 factors with eigenvalues greater than 1 and with a cumulative variance explained of 56.3\%. However, items 38, 43 and 44 were cross-loading on more than 1 factor, with scores $(.526, .505),(.531$, $.514)$ and $(.507, .571)$ respectively. Consequently, these items were removed and factor analysis was reapplied in the same way. The analysis, again, revealed 3 factors with eigenvalues greater than 1 and with a cumulative variance explained of $57.61 \%$. In this case, item 42 was not significantly (with a factor loading greater than .5) loaded on one factor and was eventually removed. When the factor analysis was reapplied for the remaining 16 items for the third time, 3 factors were extracted with a cumulative variance explained of $58.55 \%$. The factors and factor loadings are given in Table 4. The factors were named according to the relevant items. Entrepreneurship education factors refer to the need to develop new and specific entrepreneurship programmes, incorporating courses in existing programmes and in internship programmes. Networking and tutoring factors refer to the need for establishing online and offline networking and tutoring structures intended for students' needs. Academic engagement factors relate to the need for full academic engagement in entrepreneurial research and sustainability. 
Table 4. Rotated factor loadings for the 3 factors

\begin{tabular}{cccc}
\hline Item & $\begin{array}{c}\text { Factor } \mathbf{1} \\
\text { Entrepreneurship } \\
\text { education }\end{array}$ & $\begin{array}{c}\text { Factor 2 } \\
\text { Networking and } \\
\text { tutoring }\end{array}$ & $\begin{array}{c}\text { Factor 3 } \\
\text { Academic } \\
\text { engagement }\end{array}$ \\
\hline AN - 16 & 0,710 & & \\
AN - 15 & 0,697 & & \\
AN - 13 & 0,677 & & \\
AN - 14 & 0,677 & & \\
AN - 12 & 0,661 & & \\
AN - 19 & 0,661 & & \\
AN - 11 & 0,629 & & \\
AN - 17 & 0,600 & 0,847 & \\
AN - 18 & 0,580 & 0,843 & \\
AN - 20 & 0,556 & 0,587 & \\
AN - 6 & & & 0,780 \\
AN - 5 & & & 0,778 \\
AN - 7 & & 1,135 & 0,684 \\
AN - 2 & & 7,094 & \\
AN - 1 & & & \\
AN - 3 & & & \\
\hline Eigenvalue & 7,161 & & \\
Variance & & & \\
explained & 44,755 & & \\
(\%) & & & \\
\hline
\end{tabular}

To examine gender differences in educational needs in terms of entrepreneurial programme, activities and projects at an academic institution, the Mann-Whitney test was applied. Results are presented in Table 5. Only for Factor 1 (entrepreneurship education) and Factor 2 (networking and tutoring) were significant differences noted between genders. In both cases, the direction of the difference is in female students' favor with a higher rank. 
Table 5. Gender difference in educational needs

\begin{tabular}{|c|c|c|c|c|c|c|c|}
\hline Factors ( 1 not needed at all, 6 very much needed) & Gender & $\mathbf{N}$ & Mean & $\begin{array}{l}\text { Std. } \\
\text { Dvn. }\end{array}$ & $\begin{array}{l}\text { Mean } \\
\text { Rank }\end{array}$ & $\begin{array}{c}\text { Mann } \\
\text { Whitney U }\end{array}$ & $\begin{array}{l}\text { Sig. } \\
\text { level }\end{array}$ \\
\hline \multirow[t]{2}{*}{ Factor 1 - Entrepreneurship education } & Female & 2168 & 4,52 & 0,89 & 1735,40 & 1279341,5 & 0,017 \\
\hline & Male & 1241 & 4,45 & 0,93 & 1651,90 & & \\
\hline \multirow[t]{2}{*}{ Factor 2 - Networking and tutoring } & Female & 2169 & 4,65 & 1,09 & 1737,98 & 1277594 & 0,012 \\
\hline & Male & 1242 & 4,55 & 1,10 & 1650,16 & & \\
\hline \multirow[t]{2}{*}{ Factor 3 - Academic engagement } & Female & 2171 & 4,39 & 1,04 & 1708,64 & 1346804 & 0,929 \\
\hline & Male & 1243 & 4,38 & 1,07 & 1705,51 & & \\
\hline
\end{tabular}

Table 6. Test statistics for Friedmann Test

\begin{tabular}{|c|c|c|c|}
\hline & & Female & Male \\
\hline \multirow{3}{*}{$\begin{array}{l}\text { Mean } \\
\text { Rank }\end{array}$} & Factor 1 & 1,98 & 1,96 \\
\hline & Factor 2 & 2,18 & 2,15 \\
\hline & Factor 3 & 1,84 & 1,89 \\
\hline \multicolumn{2}{|r|}{$\mathrm{N}$} & 2168 & 1240 \\
\hline \multicolumn{2}{|c|}{ Chi-Square } & 142,715 & 48,971 \\
\hline \multicolumn{2}{|r|}{$d f$} & 2 & 2 \\
\hline \multicolumn{2}{|c|}{ Asymp. Sig. } & 0 & 0 \\
\hline
\end{tabular}

To explore whether there is a significant difference between factor scores, the Friedman test was applied to three factors for both genders. According to the results (Table 6) there are significant differences in factor scores. For both genders networking and tutoring structure is the highest ranked need. Entrepreneurship education is counted as the second most important requirement to foster entrepreneurial behavior. Although it scores higher than 4 for both genders, academic engagement was seen as the least important need by university students.

\section{Discussion}

Since the work of Baumol (1968), who underlined the contribution of entrepreneurship in economic growth, entrepreneurship has gained recognition as a distinguished function in today's “innovations-oriented or knowledge-based economy” (Keilbach and Sanders, 2008). Keilbach and Sanders (2008) indicate that, as articulated in the U.S. Small Business Administration (1995) report, the majority of the breakthrough innovations of the $20^{\text {th }}$ century 
were introduced by small and young companies, i.e., by entrepreneurs. This emphasizes the importance of increasing the number of entrepreneurs to support economic growth. Increasing the number of female entrepreneurs gains priority because there is still a large gap between the number of male and female entrepreneurs. Several factors contribute to this gap in entrepreneurial activity between women and men. Identifying these factors could help policy makers and educators provide appropriate supportive environments, such as educational programmes, which could encourage women to start their own business. This paper explored gender differences among university students regarding their entrepreneurial intentions as measured by perceived desirability and perceived feasibility. In addition, gender differences in students' perceptions of educational needs for effective entrepreneurial education were examined.

Consistent with previous studies (e.g. Minniti et al., 2005; Grilo and Irigoyen, 2005; Wilson et al., 2007), this study suggests that female university students are less willing to start their own business after graduation compared to the male respondents. However it is interesting that in our study, for both genders, less than half of the students are willing to engage in entrepreneurial activity. This is in contrast to Kourilsky and Walstad's (1998) study where, for both genders, more than half of the sampled high school students are willing to start a new business. Possible reasons for the lower entrepreneurial intentions in our sample might include age, educational level and, thus, differences in experience between university and high school students. The university students sampled in our study are more likely to have a realistic view towards entrepreneurship, due to their higher experience in life and knowledge, and may be daunted by the potential challenges they may encounter in an entrepreneurial career.

The first finding of our study regarding perceptive differences in terms of feasibility and desirability is that there is a significant gender difference in every statement. However, since it can be expected that students expressing similar entrepreneurial intentions might have similar feasibility and desirability perceptions, analysis was reapplied separately for students willing to start a new business and for students willing to work as a salaried employee. It was interesting to see that while among those students willing to start a new business, gender differs less, the opposite is true for the 'not willing' student group. In the 'willing' student group, the statements showing differences between genders are self-efficacy (F2 and F5) and family support (D2). Here, again, the results are consistent with the literature (e.g. Wilson et 
al., 2007; Kirkwood, 2009), illustrating that regardless of their entrepreneurial intentions women are less self-confident compared to men. Another interesting finding relates to the feeling of being supported by their families; in this regard, there is no significant difference between genders among students not willing to start a new business. This is somewhat consistent with one of the results of Linan and Santos (2007), which states that getting approval of the start-up decision from the closer environment, in our case family members, would increase the desirability level. The D2 scores of students willing to start a new business is higher than the 'not willing' group for both genders. This signifies that family support for participating in entrepreneurial activities has a positive impact on the desirability towards entrepreneurship and is definitely more decisive for those females willing to start a new business.

To explore the reflection of entrepreneurial intentions as perceived feasibility and desirability measures for the same sex, the analysis was conducted firstly among female respondents. The results confirmed our expectations. There were significant differences in terms of every feasibility and desirability statement. However, when the analysis was repeated for male respondents, interestingly there was no significant difference in F3, I would be overworked, regarding the entrepreneurial intentions. Nevertheless, it can be said that perceived feasibility and perceived desirability are capable of reflecting differences in entrepreneurial intentions.

The results of the analysis of hypotheses $\mathrm{H} 3$ and $\mathrm{H} 4$ imply that, although hypothesis $\mathrm{H} 2$ was found to be true, the sole reason for this gender difference may not be the biological sex. In particular, the lower difference observed between the genders among willing students signifies that, in case of entrepreneurial intention, biological sex is an insufficient indicator for observing differences among genders. This might be a result of the fact that entrepreneurship is seen as a more masculine area of work (Gupta et al., 2009), and that constructs chosen to analyse entrepreneurial behaviour could relate more to masculine characteristics. It could be the case that, as consistent with Watson and Newby (2005), and Gupta et al. (2009), respondents having entrepreneurial intentions display more masculine gender-role characteristics independent from their biological sex. Watson and Newby (2005) found no significant difference between male and female SME owners in terms of masculinity levels. However, our finding that female respondents have lower self-efficacy levels, even among the willing students, is somewhat consistent with the results of Mueller and Dato-on (2008), who suggested that respondents with higher masculinity would have higher entrepreneurial self- 
efficacy. Female respondents willing to start a new business have significantly lower levels of self-efficacy compared to males, but among females, they scored significantly higher than those students not willing towards entrepreneurship. To support this inference from our study further research is needed.

Another significant finding was the feasibility statement F4; 'I know enough to start a business' has the highest mean score in every analysis, meaning regardless of their intentions and gender, students are aware of their entrepreneurial knowledge deficit. However, especially in the case of not willing to start a business, females are less confident in their knowledge compared to their male correspondents.

Another important finding was that establishing entrepreneurial networking and an appropriate tutoring structure were selected by both genders as the highest need in terms of entrepreneurial programmes/activities/projects at an academic institution to foster entrepreneurship behavior. Concerning gender differences, entrepreneurship oriented education and entrepreneurial networking and tutoring structure were found to be needed more by female students. This finding is also consistent with those of previous studies cited in this paper. Since female students lack self-confidence and are more concerned about their entrepreneurial knowledge, it would seem that they would have more of a need for entrepreneurship education as well as networking and tutoring structures. These findings acknowledge Krueger and Brazeal's (1994) view regarding the ideal entrepreneurial training, which is supposed to provide self-esteem through "emotional and psychological support", "credible role models" and the necessary knowledge to promote female participation in entrepreneurship. The results are also consistent with Klyver and Grant's (2010), and Tynan et al.'s (2009) studies which emphasized the importance and need of mentoring and tutoring structures in terms of female entrepreneurship.

The findings of this study are important from the perspective of revealing gender differences in perceived desirability and perceived feasibility, which are important precursors to entrepreneurial intentions. Such elements are also important in terms of the entrepreneurial programmes/activities/projects that are needed at an academic institution to promote entrepreneurial participation among university students. Educational institutions are expected to make up part of the entrepreneurial infrastructure by supporting sole traders in their attempt to survive, grow and develop; involving target groups of innovative, fast growing and highly 
technological business entities. Our findings could help educators and policy makers design effective entrepreneurship programmes that are customized to respond to gender specific needs, especially with regard to increasing the participation of females in entrepreneurship. As mentioned in several studies, entrepreneurial intentions can be augmented by entrepreneurship education (e.g. Peterman and Kennedy, 2003; Linan, 2004; Dhaliwal, 2010). One of the main measures of success for an entrepreneurship programme should be the degree to which it boosts self-confidence through providing appropriate entrepreneurial knowledge and establishing tutoring and mentoring structures.

\section{Conclusions and Future Study}

This paper makes a contribution on a number of different levels. The first level is in the theoretical framework, which can be applied in different countries and expanded with new variables, thus providing further insights into entrepreneurial behaviors. The second is in terms of the paper's practical implications. In this regard, the key contribution of the study is in the area of design and delivery of entrepreneurship education programmes. The gender differences identified in this paper provide insights into how educators should design future content and delivery of courses that aim to increase students' willingness towards entrepreneurship. While these differences are important, equally important are the three types of activities identified as part of the educational programme.

Although the findings of our study make a significant contribution to understanding gender differences in perceived desirability and perceived feasibility towards entrepreneurial intentions and educational needs for increased entrepreneurship, there are some limitations that require future research. Our sample population mostly comprised students aged 21- 25 years, and 26 years and older. This raises the question of how, for example, their intentions towards entrepreneurship and entrepreneurship education might change if these students had prior work experience. Another point worth of further research is the degree to which students' particular areas of study affects their entrepreneurial intentions and perceptions towards entrepreneurship education needs. Furthermore, there could be country differences in terms of students' perceptions towards entrepreneurship, particularly between western and eastern European countries, given that the economic structures in these countries are so different. Such differences are also worthy of further investigation. Finally, as mentioned earlier, the assertion implied by our findings that gender stereotypes may be better indicators 
for explaining differences in perceived feasibility and desirability towards entrepreneurship for males and females needs further research to ascertain validity.

\section{References}

Ajzen, I. (1991), "The theory of planned behavior", Organizational Behavior and Human Decision Processes, Vol. 50, No. 2, pp. 179-211.

Arenius, P. and Minniti, M. (2005), "Perceptual variables and nascent entrepreneurship", Small Business Economics, Vol. 24, pp. 233-247.

Bagozzi, R., Baumgartner, H. and Yi, Y. (1989), “An investigation into the role of intentions as mediators of the attitude-behaviour relationship", Journal of Economics Psychology, Vol. 10, pp. 35-62.

Bandura, A. (1997). "Self-efficacy: The exercise of control”, W.H. Freeman Publishers, New York.

Bandura, A., Barbaranelli, C., Caprara, G., and Pastorelli, C. (2001), "Self-efficacy beliefs as shapers of children's aspirations and career trajectories", Child Development, Vol. 72, No. 1, pp. 187-206.

Baumol, W.J. (1968), "Entrepreneurship in economic theory", American Economic Review, Vol. 58, pp. 64-71.

Blanchflower, D.G., Oswald, A. and Stutzer, A. (2001), "Latent entrepreneurship across nations", European Economic Review, Vol. 45, pp. 680-691.

Brush, C.G., de Bruin, A. and Welter, F. (2009), “A gender-aware framework for women's entrepreneurship", International Journal of Gender and Entrepreneurship, Vol. 1, No. 1, pp. 8-24.

Butner, E.H. and Rosen, B. (1988), “ Bank loan officers' perceptions of the characteristics of men, women and succesful entrepreneurs", Journal of Business Venturing, Vol. 3, No. 3, pp. 249-258.

Cooney, T.M. (2009), "Developing entrepreneurship programmes for female members of the Irish traveller community", International Journal of Gender and Entrepreneurship, Vol. 1, No. 2, pp. 134-147.

Dabić, M. Bašić, M. Novak, I. Daim, T. Bayraktaroglu, E. (2012) Study of Entrepreneurial Environment Based on Cross Country Differences. Southern Journal of Entrepreneurship.Vol 4, No 2; pp. 68-86 
Dhaliwal, S. (2010), “Training women to win - A practical perspective on the training needs of women entrepreneurs", International Journal of Gender and Entrepreneurship, Vol. 2, No. 3, pp. 287-290.

De Bruin, A., Brush, C.G. and Welter, F. (2006), "Introduction to the special issue: Towards building cumulative knowledge on women's entrepreneurship", Entrepreneurship Theory and Practice, September, pp. 585-593.

Elenurm, T., Ennulo, J. and Laar, J. (2007), "Structures of motivation and entrepreneurial orientation in students as the basis for differentiated approaches in developing human resources for future business initiatives”, EBS Review, Vol. 23, No. 2, pp. 50-61.

El Harbi, S., Anderson, A. and Mansour, N. (2009), “The attractiveness of entrepreneurship for females and males in a developing Arab Muslim country; entrepreneurial intentions in Tunisia", International Business Research, Vol. 2, No. 3, pp.47-53.

Fernandez, J., Linan, F. and Santos, F.J. (2009), “Cognitive aspects of potential entrepreneurs in southern and northern Europe: An analysis using GEM-data", Revista De Economica Mundial, Vol. 23, pp.151-178.

Fitzsimmons, J.R. and Douglas, E.J. (2010), "Interaction between feasibility and desirability in the formation of entrepreneurial intentions", Journal of Business Venturing, Article in Press.

Grilo, I. and Irigoyen, J.M. (2005), "Entrepreneurship in the EU: To wish and not to be", Discussion Papers on Entrepreneurship, Growth and Public Policy, Max-Planck Institute Jena.

Guerro, M., Rialp, J. and Urbano, D. (2008), "The impact of desirability and feasibility on entrepreneurial intentions: A structural equation model", International Entrepreneurship and Management Journal, Vol. 4, pp. 35-50.

Gupta, V.K., Turban, D.B., Wasti, S.A. and Sikdar, A. (2009), "The role of gender stereotypes in perceptions of entrepreneurs and intentions to become an entrepreneur", Entrepreneurship Theory and Practice, March, pp. 397-417.

Henry, C., Hill, F. and Leitch, C. (2005a), Entrepreneurship education and training: can entrepreneurship be taught? Part I", Education + Training, Vol. 47, No. 2, pp. 98-111.

Henry, C., Hill, F. and Leitch, C. (2005b), Entrepreneurship education and training: can entrepreneurship be taught? Part II", Education + Training, Vol. 47, No. 3, pp. 158169.

Hines, G. (1973), “Achievement motivation, occupations and labour turnover on New Zealand”, Journal of Applied Psychology, Vol. 58, No. 3, pp. 313-317. 
Keilbach, M. and Sanders, M. (2008), "The contribution of entrepreneurship to economic growth", in Keilbach, M. et al. (Eds.), Sustaining Entrepreneurship and Economic Growth - Lessons in Policy and Industry Innovastions from Germany and India, Springer Science + Business Media, pp. 7-25.

Kelley, D., Bosma, N. and Amoros, J.E. (2010), Global Entrepreneurship Monitor 2010 Global Report, Babson College, Universidad del Desarrollo and London Business School.

Kickul, J., Wilson, F., Marlino, D. and Barbosa, S.D. (2008), "Are misalignments of perceptions and self-efficacy causing gender gaps in entrepreneurial intentions among our nations' teens?", Journal of Small Business and Enterprise Development, Vol. 15, No. 2, pp. 321-335.

Kirkwood, J. (2009), “Is a lack of self-confidence hindering women entrepreneurs?", International Journal of Gender and Entrepreneurship, Vol. 1, No. 2, pp. 118-133.

Klyver, K. and Grant, S. (2010), “Gender differences in entrepreneurial networking and participation", International Journal of Gender and Entrepreneurship, Vol. 2, No. 3, pp. 213-227.

Kourilsky, M.L. and Walstad, W.B (1998), "Entrepreneurship and female youth: knowledge, attitudes, gender differences, and educational practices", Journal of Business Venturing, Vol. 13, No. 1, pp. 77-88.

Krueger, N. (1993), “The impact of prior entrepreneurial exposure on perceptions of new venture feasibility and desirability", Entrepreneurship Theory and Practice, Fall, pp. 521.

Krueger, N. and Brazeal, D. (1994), "Entrepreneurial potential and potential entrepreneurs", Entrepreneurship Theory and Practice, Spring, pp. 91-104.

Krueger, N., Reilly, M. and Carsrud, A. (2000), "Competing models of entrepreneurial intentions", Journal of Business Venturing, Vol. 15, No. 5/6, pp. 411-432.

Linan, F. (2004), "Intention-based models of entrepreneurship education”, Piccolla Impresa / Small Business, Iss. 3, pp. 11-35.

Linan, F. (2008), "Skill and value perceptions: How do they affect entrepreneurial intentions?”, Int. Entrep. Manag. J., Vol. 4, pp. 257-272.

Linan, F. and Chen, Y. (2009), "Development and cross-cultural application of a specificintrument to measure entrepreneurial intentions", Entrepreneurship Theory and Practice, May, pp. 593-617. 
Linan, F. and Santos, F.J. (2007), “Does social capital affect entrepreneurial intentions?”, Int. Adv. Econ. Res., Vol. 13, pp. 443-453.

Lunati, M., Schlochtern, J.M. and Sargsyan, G. (2010), "Measuring Entrepreneurship - The OECD - Eurostat Entrepreneurship Indicators Programme", OECD Statistics Brief, No. 15, pp.1-12.

Marlino, D. and Wilson, F. (2003), “Teen girls on business: Are they being empowered?", Report, Simmons School of Management and The Committee of 200, Boston, MA.

Menzies, T. and Tatroff, H. (2006), "The propensity of male vs female students to take courses and degree concentrations in entrepreneurship", Journal of Small Business and Entrepreneurship, Vol. 19, No. 2, pp. 203-223.

Minniti, M., Arenius, P. and Langowitz, N. (2005), "2004 report on women and entrepreneurship", In Wellesley, M.A., Global Entrepreneurship Monitor, The Center for Women's Leadership, Babson College.

Minniti, M. and Nardone, C. (2007), "Being in someone else's shoes: the role of gender in nascent entrepreneurship", Small Business Economics, Vol. 28, pp. 223-238.

Mueller, S.L. and Dato-on, M.C. (2008), "Gender-role orientation as a determinant of entrepreneurial self-efficacy", Journal of Developmental Entrepreneurship, Vol. 13, No. 1, pp. 3-20.

Peterman, N.E. and Kennedy, J. (2003), “Enterprise education: Influencing students' perceptions of entrepreneurship", Entrepreneurship Theory and Practice, Winter, pp. 129-144.

Petridou, E., Sarri, A. and Kyrgidou, L.P. (2009), "Entrepreneurship education in higher educational institutions: the gender dimension", Gender in Management: An International Journal, Vol. 24, No. 4, pp. 286-309.

Roomi, M.A. and Harrison, P. (2010), "Behind the veil: Women-only entrepreneurship training in Pakistan", International Journal of Gender and Entrepreneurship, Vol. 2, No. 2, pp. 150-172.

Roper, S. and Scott, J.M. (2009), "Perceived financial barriers and start-up decision: An econometric analysis of gender differences using GEM data", International Small Business Journal, Vol. 27, No. 2, pp. 149-171.

Segal, G., Borgia, D. and Schoenfeld, J. (2005), "The motivation to become an entrepreneur", International Journal of Entrepreneurial Behaviour and Research, Vol. 11, No.1, pp. 42-57. 
Shapero, A. (1982), "Social Dimensions of Entrepreneurship", in Summers, D.F. (2000), The Formation of Entrepreneurial Intentions. New York: Garland Publishing Inc.

Summers, D.F. (2000), The Formation of Entrepreneurial Intentions, Garland Publishing Inc., New York.

Turker, D. and Selcuk, S.S. (2008), „Which factors affect entrepreneurial intentions of university students?", Journal of European Industrial Training, Vol. 33, No. 2, pp. 142-159.

Tynan, M., Thomas, D., Durand, M., O’Gorman, B. and Fuller-Love, N. (2009), “Training female entrepreneurs: Lessons from the FEIW Project", International Journal of Gender and Entrepreneurship, Vol. 1, No. 3, pp. 253-260.

Veciana, J.M., Aponte, M. and Urbano, D. (2005), “University students' attitudes towards entrepreneurship: A two country comparison", International Entrepreneurship and Management Journal, Vol. 1, pp. 165-182.

Verheul, I., van Stel, A. and Thurik, R. (2004), "Explaining female entrepreneurship across 29 countries", Discussion Papers on Entrepreneurship, Growth and Public Policy. MaxPlanck Institute, pp 1-32.

Wang, C.K. and Wong, P. (2004), "Entrepreneurial interest of university students in Singapore", Technovation, Vol. 24, pp. 163-172.

Watson, J. and Newby, R. (2005), "Biological sex, stereotypical sex-roles, and SME owner characteristics", International Journal of Entrepreneurial Behaviour and Research, Vol. 11, No. 2, pp. 129-143.

Wilson, F., Kickul, J. and Marlino, D. (2007), "Gender, entrepreneurial self-efficacy, and entrepreneurial career intentions: Implications for entrepreneurship education, Entrepreneurship Theory and Practice, May, pp. 387-406.

Wilson, F., Marlino, D. and Kickul, J. (2004), “Our entrepreneurial future: Examining the diverse attitudes and motivations of teens across gender and ethnic identity", Journal of Developmental Entrepreneurial, Vol. 9, No. 3, pp. 177-197.

Wu, S. and Wu, L. (2008), "The impact of higher education on entrepreneurial intentions of university students in China", Journal of Small Business and Enterprise Development, Vol. 15, No. 4, pp. 752-774.

Zhang, Z., Zyphur, M.J., Narayanan, J., Arvey, R.D., Chaturvedi, S., Avolio, B.J., Lichtenstein, P. and Larsson, G. (2009), "The genetic basis of entrepreneurship: Effects of gender and personality”, Organizational Behavior and Human Decision Processes, Vol. 110, pp. 93-107. 